\title{
The occurrence of Echinorhynchus salmonis Müller, 1784 in benthic amphipods in the Baltic Sea
}

\author{
Daniel P. Benesh ${ }^{1,2}$, Raija-Liisa Aura ${ }^{1}$, Ann-Britt Andersin ${ }^{3}$ and E. Tellervo Valtonen ${ }^{1}$ \\ ${ }^{1}$ Department of Biological and Environmental Science, University of Jyväskylä, Finland; \\ ${ }^{2}$ Marine Science Institute, University of California, Santa Barbara, CA, USA; \\ ${ }^{3}$ Kappelisatamantie, Hanko Pohjoinen, Finland
}

\begin{abstract}
The acanthocephalan Echinorhynchus salmonis Müller, 1784 is a common parasite of salmonid fish, but it has rarely been reported from an intermediate host. Samples of benthic amphipods, Monoporeia affinis (Lindström), were taken from multiple, deep sites (usually below $70 \mathrm{~m}$ ) in the Gulf of Bothnia over the course of more than a decade and examined for acanthocephalans. Overall, only $0.44 \%$ of 23296 amphipods were infected, all with just a single worm. This prevalence is consistent with several previous reports of acanthocephalans in deep-water, benthic amphipods, but it appears low compared to that often reported for acanthocephalan species infecting littoral amphipods. Parasite occurrence did not exhibit a clear regional pattern (i.e. northern $v s$ southern sites) nor did it have any relationship with site depth. At sites sampled over multiple years, parasite abundance was consistently low (mostly $<0.01)$, though two spikes in abundance (over 0.06) were also observed, indicating that infection can be substantially higher at particular times or in particular places. The median density of E. salmonis in samples containing the parasite was estimated as 8.4 cystacanths per $\mathrm{m}^{2}$.
\end{abstract}

Keywords: Acanthocephala, aggregation, Gulf of Bothnia, cystacanth, density, Echinorhynchidae, Echinorhynchus gadi, intermediate host, repeatability

Acanthocephalans in the genus Echinorhynchus Zoega in Müller, 1776 infect fish as definitive hosts and, for those species with known life cycles, amphipods as intermediate hosts (Schmidt 1985), though there are exceptions (e.g. E. bothniensis Zdzitowiecki et Valtonen, 1987 infects mysids; see Väinölä et al. 1994). At least four species of Echinorhynchus occur in the Gulf of Bothnia, the northernmost part of the Baltic Sea. Echinorhynchus salmonis Müller, 1784 is particularly common, infecting 17 fish species (Valtonen and Crompton 1990). The benthic amphipod Monoporeia affinis (Lindström) is the major component of the macrozoobenthos in this area (Andersin et al. 1984, Laine 2003) and an important food item for fish (Segerstråle 1950, Aneer 1975). It is the intermediate host of E. salmonis. Although amphipod populations in the Baltic have been monitored for decades (HELCOM 2009), little is known about the abundance of acanthocephalans in M. affinis.

We describe the occurrence of E. salmonis in amphipod samples taken from multiple sites over a period of more than a decade and we explored the pattern of parasite abundance across these samples. Abundances may be expected a priori to differ widely, given that a number of environmental variables (salinity, productivity, oxygen, temperature) vary spatiotemporally in the Baltic Sea (HELCOM
2009). We also report the tangential finding of Echinorhynchus gadi Zoega in Müller, 1776 from Pontoporeia femorata Krøyer, another benthic amphipod that occupies a niche similar to M. affinis (Hill and Elmgren 1987, Byrén et al. 2002). Parts of these data were previously reported by Aura et al. (1990) in a conference abstract. We provide a more complete description of the data, including precise sample sizes, analyses of spatiotemporal patterns and estimates of parasite density. Our study adds to the relative paucity of information on the occurrence of acanthocephalans in intermediate hosts collected from deep, benthic habitats (Amin 1978, Marcogliese 1994, Zdzitowiecki and Presler 2001, Laskowski et al. 2010).

\section{MATERIALS AND METHODS}

The Baltic Sea is the world's largest body of brackish water. Our sampling sites were mostly in the Gulf of Bothnia in the northern Baltic, which is characterised by lower salinity $(<5 \mathrm{ppt})$ and no near-bottom oxygen deficiencies. Many taxa occurring in these areas are freshwater species (HELCOM 2009). Benthic amphipods were sampled from 12 sites in the Bothnian Bay (North Gulf of Bothnia), 4 sites in the Bothnian Sea (South Gulf of Bothnia) and one site in the Gulf of Finland (Fig. 1). A few sites were sampled multiple times, usually in different years. Sampling took place in early summer ( 32 of 45 samples were taken in June or 


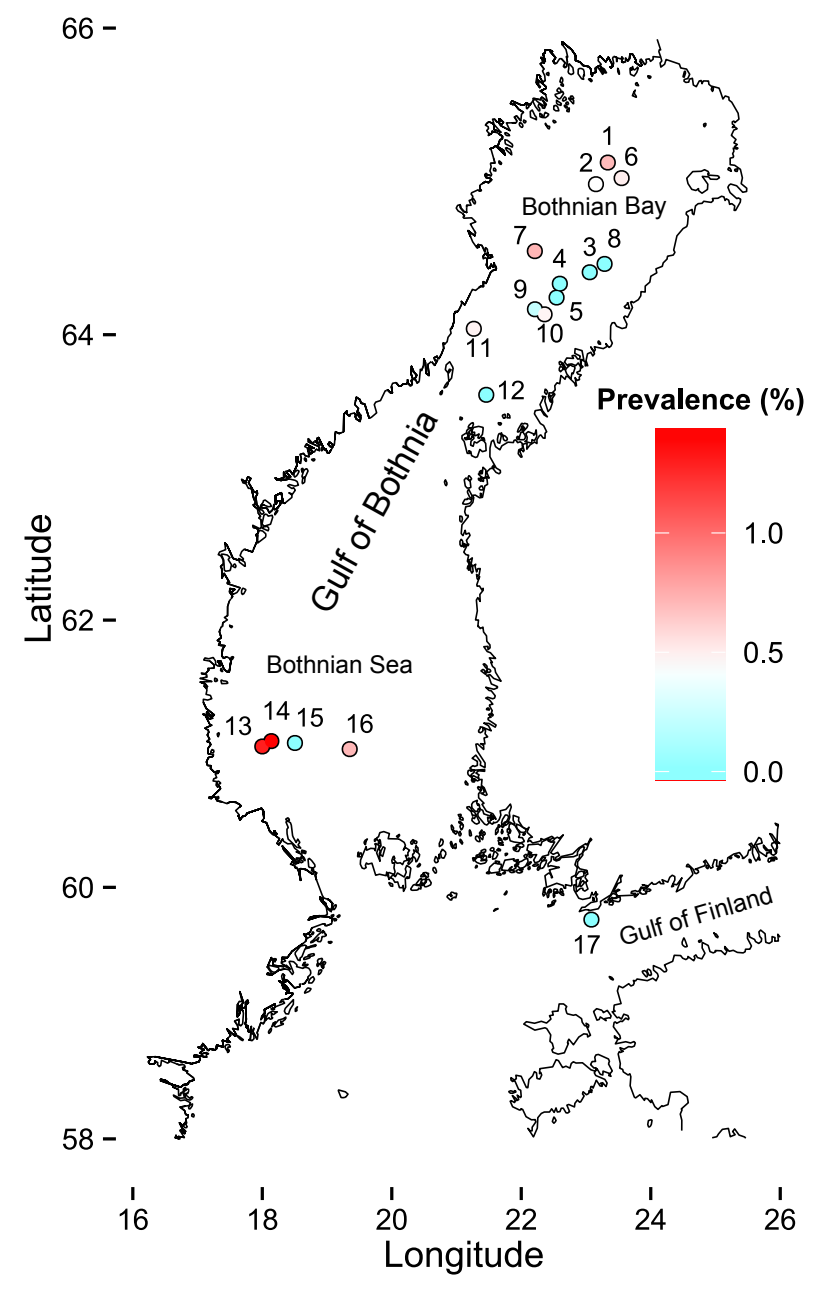

Fig. 1. Sampling sites in the Baltic Sea. Site numbers correspond to those in Table 1. A color gradient indicates the prevalence of Echinorhynchus salmonis in Monoporeia affinis after pooling all samples from a given site.

July), but a few samples were taken earlier (5 in May) or later (8 from August to November). A van Veen grab sampler (sampling area $\sim 0.1 \mathrm{~m}^{2}$ ) was used to collect benthic samples that were then put through a sieve with $1 \mathrm{~mm}^{2}$ mesh size. Given this mesh size, the youngest amphipods were not sampled.

Amphipods were stored in $4 \%$ buffered formalin and subsamples were dissected for larval acanthocephalans under a binocular microscope. Recovered acanthocephalans were stored in $70 \%$ ethanol, stained with Grenacher's borax carmine, dehydrated through an ethanol gradient, cleared in xylene and mounted in Canada balsam (Asaolu et al. 1981). Specimens were identified as E. salmonis on the basis of their body form, cement glands and proboscis characteristics (see Shostak et al. 1986).

The samples were collected as a part of other quantitative studies on the benthic fauna, some of which measured amphipod density (Andersin et al. 1984, Lehtonen and Andersin 1998). Densities were calculated as the average of several, parallel samples (from 2 to 10) collected from a given site at a given time. We multiplied amphipod density and parasite abundance to produce estimates of parasite density. The terms prevalence, abundance, intensity and density are used as defined by Bush et al. (1997).

For sites sampled multiple times, we examined the temporal stability of infection rates using Fisher's exact tests. We also examined
Table 1. Samples of Monoporeia affinis (Lindström) from the Baltic Sea (for location of sampling site - see Fig. 1) examined for infection with Echinorhynchus salmonis Müller, 1784.

\begin{tabular}{|c|c|c|c|c|c|c|}
\hline Site & $\begin{array}{l}\text { Latitude } \\
\text { (N) }\end{array}$ & $\begin{array}{l}\text { Longitude } \\
\text { (E) }\end{array}$ & Depth $(m)^{\mathrm{a}}$ & $\begin{array}{c}\text { Number of } \\
\text { samples }\end{array}$ & $\begin{array}{l}\text { Amphipods } \\
\text { dissected }\end{array}$ & Worms \\
\hline 1 & 65.14 & 23.34 & 71 & 15 & 8084 & 56 \\
\hline 2 & 65.00 & 23.15 & 87 & 4 & 924 & 4 \\
\hline 3 & 64.42 & 23.06 & 81 & 1 & 33 & 0 \\
\hline 4 & 64.34 & 22.60 & 92 & 1 & 120 & 0 \\
\hline 5 & 64.25 & 22.55 & 80 & 1 & 85 & 0 \\
\hline $6^{\mathrm{b}}$ & 65.04 & 23.55 & $\mathrm{~b}$ & 1 & 407 & 2 \\
\hline 7 & 64.56 & 22.21 & 91 & 2 & 1684 & 12 \\
\hline 8 & 64.48 & 23.29 & 81 & 1 & 112 & 0 \\
\hline 9 & 64.17 & 22.21 & 109 & 9 & 3304 & 7 \\
\hline 10 & 64.14 & 22.36 & 91 & 1 & 432 & 2 \\
\hline 11 & 64.04 & 21.27 & 94 & 1 & 211 & 1 \\
\hline 12 & 63.59 & 21.46 & 80 & 1 & 854 & 0 \\
\hline $13^{b}$ & 61.07 & 18.00 & $\mathrm{~b}$ & 1 & 233 & 3 \\
\hline 14 & 61.11 & 18.14 & 74 & 1 & 634 & 9 \\
\hline 15 & 61.10 & 18.50 & 65 & 1 & 326 & 0 \\
\hline 16 & 61.05 & 19.35 & 126 & 1 & 1006 & 7 \\
\hline $17^{\mathrm{c}}$ & 59.51 & 23.16 & 36 & 3 & 4847 & 0 \\
\hline Total & - & - & - & 45 & 23296 & 103 \\
\hline
\end{tabular}

aaverage across multiple samples; depth measurements were relatively consistent within sites; ${ }^{b}$ coordinates were approximate for sites 6 and 13. Depth was not measured at these two sites, but it is presumably deeper than $70 \mathrm{~m}$; ${ }^{\mathrm{c}}$ four samples of another amphipod species (Pontoporeia femorata Krøyer) were taken at this site. Out of 1695 dissected amphipods, $15(0.88 \%)$ were infected with Echinorhynchus gadi Zoega in Müller, 1776.

spatial patterns. Generalised linear mixed effects models, with site as a random effect, binomial error distribution and a logit link (Wilson and Grenfell 1997, Bolker et al. 2009), were used to explore the effect of site depth and region (Bothnian Bay, Bothnian Sea, Gulf of Finland) on E. salmonis prevalence. All analyses were conducted in R 3.1.0 (R Development Core Team, Vienna, Austria).

\section{RESULTS}

Monoporeia affinis was collected from all sites. Of 23296 amphipods dissected, 103 were infected with the acanthocephalan Echinorhynchus salmonis (Table 1). All infections involved a single worm, so that the overall prevalence and abundance were equivalent $(=0.0044)$. Additionally, a second amphipod species was collected at the Gulf of Finland site, Pontoporeira femorata, and found to be infected with E. gadi (prevalence and abundance $=0.0088$ ).

The distribution of parasite abundance across samples was clearly skewed (Fig. 2), such that no or few parasites were found in most samples, with a few samples having relatively high abundance (up to 0.128). Five sites were sampled multiple times (Table 1). The infection rate varied significantly between temporal samples in two of five sites (Fisher's exact tests, site 1: $\chi_{14}^{2}=36.36, \mathrm{P}=0.008, E$. gadi in site $\left.17: \chi_{3}^{2}=78.16, \mathrm{P}<0.001\right)$. However, when the sample with the highest infection rate in each of these two sites is excluded, then these tests were no longer significant (site 1: $\chi_{13}^{2}=12.85, \mathrm{P}=0.43$, site $18: \chi_{2}^{2}=0.59, \mathrm{P}=0.83$ ), suggesting a pattern of temporal stability with an occasional spike in the infection rate (Fig. 3). In fact, these two 'spikes' were the only samples with prevalence above $3 \%$. 


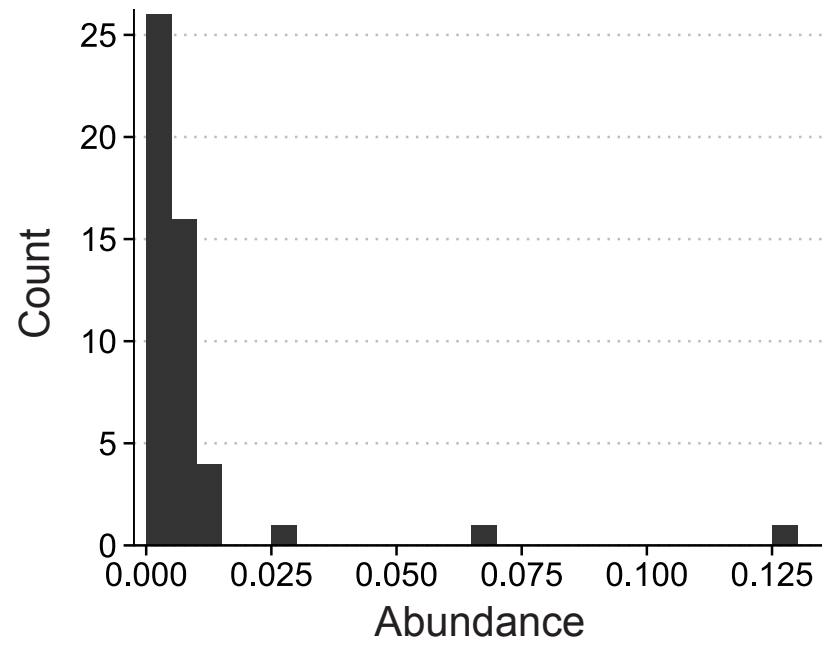

Fig. 2. Frequency distribution of acanthocephalan abundance in 49 samples of benthic amphipods.

The analysis of spatial patterns indicated that models with just 'depth' or just 'region' were slight improvements over models without these variables (likelihood ratio tests: $\chi_{1}^{2}=3.49, \mathrm{P}=0.06$ and $\chi_{2}^{2}=14.53, \mathrm{P}<0.001$, respectively). However, these effects were completely driven by the single Gulf of Finland site, which was the shallowest site and characterised by an apparent absence of E. salmonis (Table 1). When this site was removed, there was no relationship with depth $\left(\chi_{1}^{2}=0.004, \mathrm{P}=0.95\right)$ and little difference between the northern and southern parts of the Gulf of Bothnia $\left[\chi_{1}^{2}=2.95, \mathrm{P}=0.09\right.$; mean $\mathrm{N}$ vs $\mathrm{S}(95 \% \mathrm{CI})$ : $0.38 \%(0.23-0.62 \%)$ vs $0.79 \%(0.36-1.75 \%)]$.

The estimated density of $M$. affinis ( $\mathrm{n}=38$ samples) ranged from 237 to 4057 specimens $/ \mathrm{m}^{2}$ (median 1071) and there was no relationship between density and infection rate across samples (mixed model: $\chi_{1}^{2}=0.27, \mathrm{P}=0.60$ ). Amphipod density and parasite abundance were multiplied to estimate the density of larval acanthocephalans; when present in a sample, E. salmonis ranged from 2.1 to 44.8 specimens $/ \mathrm{m}^{2}$ (median 8.4 ).

\section{DISCUSSION}

Our data add to the handful of reports of Echinorhynchus salmonis (see Van Cleave 1920, DeGuisti and Budd 1959, Brownell 1970) and E. gadi (see Nybelin 1923, Valter et al. 1980, Valtonen et al. 1983) in various amphipod species. The overall prevalence of $E$. salmonis across all our Baltic Sea samples was $0.44 \%$; the prevalence of $E$. gadi at site 17 was $0.88 \%$. Several studies on acanthocephalans in amphipods from deep, benthic habitats have found comparable infection rates, e.g. $0.8 \%$ for $E$. gadi (see Marcogliese 1994), 0.1\% for E. salmonis in lake Michigan (Amin 1978); $0.32-1.19 \%$ for several Antarctic species (Zdzitowiecki and Presler 2001, Laskowski et al. 2010). These values are low compared to those often reported from acanthocephalans in littoral lake or stream amphipods. For example, Echinorhynchus truttae Schrank, 1788, a parasite of brown trout, has been found at prevalences of 1 to $4 \%$ in amphipods (1-4\% - Scheer 1935, 2.3\% - Okaka 1984, 2.8\% Lassiere 1989, 4.1\% - MacNeil et al. 2003, 1.3\% - Dez-

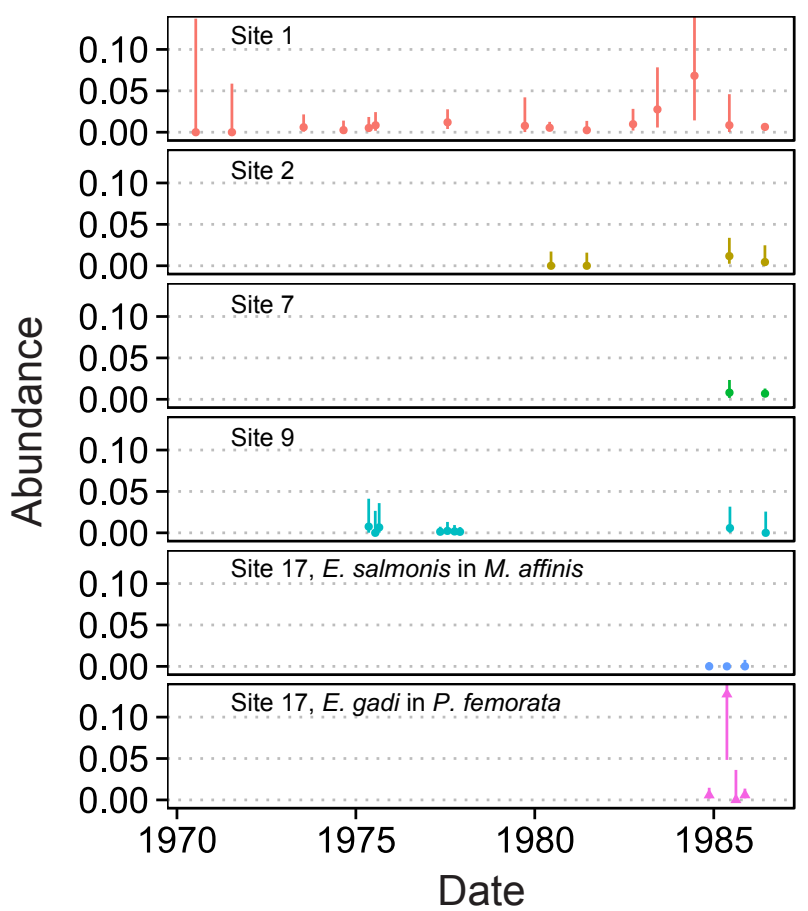

Fig. 3. Temporal variation in abundance of acanthocephalans (Echinorhynchus salmonis and E. gadi) in samples of amphipod (Monoporeia affinis and Pontoporeia femorata) taken from several sites (see Fig. 1). Panels are split by site. Error bars represent the $95 \%$ CI.

fuli et al. 2008), whereas Pomphorhynchus laevis Zoega in Müller, 1776, a well-studied species usually infecting cyprinid fish, has often been reported to occur at prevalences above 10\% in amphipods (Hine and Kennedy 1974, Brown and Pascoe 1989, Moravec and Scholz 1991, Dezfuli et al. 1999). In contrast, Okaka (1984) reported a low prevalence of E. salmonis $(0.9 \%)$ in gammarids from a shallow river, while Nybelin (1924) found a high prevalence $(8.8 \%)$ of E. salmonis in $160 \mathrm{M}$. affinis sampled off the east coast of Sweden (exact sampling location and depth were not given, but presumably it was sublittoral). Green (1965) also noted up to $12 \%$ prevalence of E. salmonis in the largest size class of $M$. affinis collected from the bottom of a glacial lake in New York. However, only $1-2 \%$ of individuals in Green's (1965) samples were in the largest size class, so the overall prevalence of E. salmonis in his study was considerably lower (we roughly calculated it as about $1 \%$ ). Thus, acanthocephalan infection rates are not always lower in benthic amphipods compared to littoral amphipods, and additional studies are needed to assess whether there is a general difference between habitats.

Although only 1 in 227 M. affinis was infected on average, prevalence was much higher in a few samples. The aggregated distribution of abundances across samples is a typical pattern in ecology (Taylor 1961, Taylor et al. 1978, Gaston et al. 2006), and it has also been noted for parasites (Morand and Guégan 2000, Krasnov et al. 2006, Pérez-delOlmo et al. 2011). Both spatial and temporal variation in abundance of larvae E. salmonis contributes to this pattern. Sites that were sampled multiple times exhibited consistent, low parasite abundance, but occasional increases in 
abundance were observed. Some sites may also be more or less conducive to parasite existence. For example, the parasite was not found at the shallow, near-coast Gulf of Finland site, despite intense sampling, while two sites in the Bothnian Sea seemed to have higher prevalence (Fig. 1, Table 1). However, we did not find infection rates to differ consistently across the Gulf of Bothnia (North vs South) or with sampling depth. These analyses had rather low power, though, and would benefit from further sampling, e.g. in the Bothnian Sea and at additional shallow sites. Valter et al. (1980) also found prevalence of E. gadi in amphipods to vary widely (from 0.5 to $6.3 \%$ ), although the distribution of prevalence values was not explicitly investigated.

The precise spatiotemporal factors leading to higher larval acanthocephalan abundance remain to be determined. Environmental variables, like salinity and oxygen, vary across the study area, perhaps influencing parasite transmission. For example, E. gadi was only found at the southernmost site, presumably because the higher salinity there suits $P$. femorata (see Laine 2003) and cod, an important definitive host (Valtonen and Crompton 1990). Amphipod populations in the northern Baltic also exhibit both seasonal and long-term fluctuations in response to nutrient input (Lehtonen and Andersin 1998). However, parasite abundance appeared unrelated to the density of amphipods in the sample, so it is not obvious that there is a tight coupling between amphipod and acanthocephalan populations. Similarly, Valtonen et al. (2004) found that the abundance of three seal acanthocephalans in the Bothnian Bay varied little in response to sizeable fluctuations in the intermediate and definitive host populations.

Our study is one of the few to examine the distribution of an acanthocephalan in a benthic amphipod. We found that very low infection rates are the norm for this system ( $87 \%$ of our samples exhibited prevalence less than $1 \%$ ), but we also found that at particular times or in particular places, infection can be substantially higher. This heterogeneous pattern of occurrence in amphipods is expected to translate into a more aggregated distribution in the fish definitive host (Janovy and Kutish 1988, Lotz et al. 1995). In the study area, E. salmonis is indeed overdispersed in its main definitive hosts (Valtonen and Crompton 1990). Infection rates in fish are also much higher than in amphipods, e.g. in Coregonus lavaretus widegreni Malmgren: prevalence 44\% and abundance 9.9 (Valtonen and Crompton 1990). So even though the density of larval acanthocephalans seems quite low (at a maximum, just tens of individuals per $\mathrm{m}^{2} v s$ thousands of amphipods per $\mathrm{m}^{2}$ ), it is sufficient to maintain sizeable adult acanthocephalan populations in fish.

Acknowledgements. We thank the Tvärminne Zoological station, Helsinki University, for material and the Finnish Environment Institute (SYKE) for help with collecting and collating the data. Helpful reviewer feedback substantially improved the manuscript. DPB gratefully acknowledges support from the DFG (BE $5336 / 1-1)$

\section{REFERENCES}

Amin O. 1978: On the crustacean hosts of larval acanthocephalan and cestode parasites in southwestern Lake Michigan. J. Parasitol. 64: 842-845.

Andersin A.-B., Lassig J., Sandler H. 1984: On the biology and production of Pontoporeia affinis Lindstr. in the Gulf of Bothnia. Limnologica 15: 395-401.

Aneer G. 1975: Composition of food of the Baltic herring (Clupea harengus v. Membras L.), fourhorn sculpin (Myoxocephalus quadricornis L.) and eel-pout (Zoarces viviparus L.) from deep soft bottom trawling in the Askö-Landsort area during two consecutive years. Merentutkimuslait. Julk./Havsforskningsinst. Skr. 239: 146-154.

Asaolu S.O., Wh-itfield P.J., Crompton D.W.T., Maxwell L. 1981: Observations on the development of the ovarian balls of Moniliformis (Acanthocephala). Parasitology 83: 23-32.

Aura R.-L., Valtonen E.T., Andersin A.-B. 1990: On the acanthocephalan infection in some glacial relict crustaceans in Finland. Ann. Zool. Fenn. 27: 245.

Bolker B.M., Brooks M.E., Clark C.J., Geange S.W., Poulsen J.R., Stevens M.H.H., White J.-S.S.S. 2009: Generalized linear mixed models: a practical guide for ecology and evolution. Trends Ecol. Evol. 24: 127-135.

Brown A.F., Pascoe D. 1989: Parasitism and host sensitivity to cadmium: an acanthocephalan infection of the freshwater amphipod Gammarus pulex. J. Appl. Ecol. 26: 473-487.

Brownell W.N. 1970: Comparison of Mysis relicta and Pontoporeia affinis as possible intermediate hosts for the acanthocephalan Echinorhynchus salmonis. J. Fish. Res. Brd. Can. 27: $1864-1866$.

Bush A.O., Lafferty K.D., Lotz J.M., Shostak A.W. 1997: Parasitology meets ecology on its own terms: Margolis et al revisited. J. Parasitol. 83: 575-583.
Byrén L., Ejdung G., Elmgren R. 2002: Comparing rate and depth of feeding in benthic deposit-feeders: a test on two amphipods, Monoporeia affinis (Lindström) and Pontoporeia femorata Kröyer. J. Exp. Mar. Bio. Ecol. 281: 109-121.

DeGuisti D., Budd J. 1959: A three-year survey of the infection rate of Echinorhynchus coregoni and Cyathocephalus truncatus in their intermediate host Pontoporeia affinis from South Bay Mouth, Ontario. J. Parasitol. 45 (Sec. 2): 25.

Dezfuli B.S., Lui A., Giovinazzo G., Giari L. 2008: Effect of Acanthocephala infection on the reproductive potential of crustacean intermediate hosts. J. Invertebr. Pathol. 98: 116-119.

Dezfuli B.S., Rossetti E., Bellettato C.M., Maynard B.J. 1999: Pomphorhynchus laevis in its intermediate host Echinogammarus stammeri in the River Brenta, Italy. J. Helminthol. 73: 95-102.

Gaston K.J., Borges P. a V, He F., Gaspar C. 2006: Abundance, spatial variance and occupancy: arthropod species distribution in the Azores. J. Anim. Ecol. 75: 646-656.

Green R.H. 1965: The Population Ecology of the Glacial Relict Amphipod Pontoporeia affinis Lindstrom in Cayuga Lake, New York. PhD thesis, Cornell University, Itaca, New York, 116 pp.

HELCOM 2009: Biodiversity in the Baltic Sea - An Integrated Thematic Assessment on Biodiversity and Nature Conservation in the Baltic Sea. Helsinki Commission, Helsinki, 192 pp.

Hill C., Elmgren R. 1987: Vertical distribution in the sediment in the co-occurring benthic amphipods Pontoporeia affinis and P. femorata. Oikos 49: 221-229.

Hine P., Kennedy C. 1974: The population biology of the acanthocephalan Pomphorhynchus laevis (Müller) in the River Avon. J. Fish Biol. 6: 665-679.

Janovy J., Kutish G. 1988: A model of encounters between host and parasite populations. J. Theor. Biol. 134: 391-401. 
Krasnov B.R., Stanko M., Miklisova D., Morand S. 2006: Host specificity, parasite community size and the relation between abundance and its variance. Evol. Ecol. 20: 75-91.

LAINE A.O. 2003: Distribution of soft-bottom macrofauna in the deep open Baltic Sea in relation to environmental variability. Estuar. Coast. Shelf Sci. 57: 87-97.

Laskowski Z., Jeżewski W., ZdZitowiecki K. 2010: New data on the occurrence of Acanthocephala in Antarctic Amphipoda. Acta Parasitol. 55: 161-166.

LASSIERE O.L. 1989: The ecology of Neoechinorhynchus rutili (Acanthocephala) in Scottish freshwater lochs. PhD thesis, University of Glasgow.

Lehtonen K.K., Andersin A.B. 1998: Population dynamics, response to sedimentation and role in benthic metabolism of the amphipod Monoporeia affinis in an open-sea area of the northern Baltic Sea. Mar. Ecol. Prog. Ser. 168: 71-85.

Lotz J., Bush A., Font W. 1995: Recruitment-driven, spatially discontinuous communities: a null model for transferred patterns in target communities of intestinal helminths. J. Parasitol. 81: $12-24$.

MacNeil C., Fielding N.J., Hume K.D., Dick J.T., Elwood R.W., Hatcher M.J., DunN A.M. 2003: Parasite altered micro-distribution of Gammarus pulex (Crustacea: Amphipoda). Int. J. Parasitol. 33: 57-64.

Marcogliese D. 1994: Aeginina longicornis (Amphipoda: Caprellidea), new intermediate host for Echinorhynchus gadi (Acanthocephala: Echinorhynchidae). J. Parasitol. 80: 1043-1044.

Morand S., GuÉGan J.F. 2000: Distribution and abundance of parasite nematodes: ecological specialisation, phylogenetic constraint or simply epidemiology? Oikos. 88: 563-573.

Moravec F., Scholz T. 1991: Observations on the biology of Pomphorhynchus laevis (Zoega in Müller, 1776) (Acanthocephala) in the Rokytna River, Czech and Slovak Federative Republic. Helminthologia 28: 23-29.

Nybelin O. 1923: Zur postembryonalen Entwicklungsgeschichte der Acanthcephalen I. Zool. Anz. 58: 32-36.

Nybelin O. 1924: Zur postembryonalen Entwicklungsgeschichte der Acanthcephalen II. Zool. Anz. 61: 190-193.

Окака C.E. 1984: Studies on the biology of Cyathocephalus truncatus (Pallas, 1781) (Cestoda: Spathebothridea) in its fish and crustacean hosts. PhD thesis, University of Leeds, Leeds, 259 pp.

Pérez-del-Olmo A., Morand S., Raga J.A., Kostadinova A. 2011: Abundance-variance and abundance-occupancy relation- ships in a marine host-parasite system: the importance of taxonomy and ecology of transmission. Int. J. Parasitol. 41: 1361-1370.

SCHeER D. 1935: Die Jugendform des acanthocephalen Echinorhynchus truttae Schrank und ihr Vorkommen in Gammarus Pulex. Z. Parasitenkd. 7: 440-442.

Schmidt G. 1985: Development and life cycles. In: D.W.T. Crompton and B.B. Nickol (Eds.), Biology of the Acanthocephala. Cambridge University Press, Cambridge, pp. 273-305.

SegerstrÅLE S.G. 1950: The amphipods on the coasts of Finland: Some facts and problems. Biol. Soc. Sci. Fenn. 10: 1-28.

Shostak A.W., Dick T.A., Szalai A.J., Bernier L.M.J. 1986: Morphological variability in Echinorhynchus gadi, E. leidyi, and E. salmonis (Acanthocephala: Echinorhynchidae) from fishes in northern Canadian waters. Can. J. Zool. 64: 985-995.

TAYLOR L.R. 1961: Aggregation, variance and the mean. Nature. 189: 732-735.

Taylor L.R., Woiwod I.P., Perry J.N. 1978: The density dependence of spatial behaviour and the rarity of randomness. J. Anim. Ecol. 47: 383-406.

Väinölä R., VALtonen E., Gibson D. 1994: Molecular systematics in the acanthocephalan genus Echinorhynchus (sensu lato) in northern Europe. Parasitology 108: 105-114.

Valter E.D., Kondrashkova A.N., Popova T.I. 1980: [Caprella septentrionalis Kroyer, an intermediate host of the acanthocephalan Echinorhynchus gadi Müller, 1776.] In: Voprosy Parazitologii Vodnykh Bespozvonochnykh Zhivotnykh (Tematicheskii Sbornik). Akademiya Nauk Litovskoi SSR, Vilnius, Russia, pp. 19-20. (In Russian.)

Van Cleave H. 1920: Notes on the life cycle of two species of Acanthocephala from freshwater fishes. J. Parasitol. 6: 167-172.

Valtonen E.T., Crompton D.W.T. 1990: Acanthocephala in fish from the Bothnian Bay, Finland. J. Zool. 220: 619-639.

Valtonen E.T., Helle E., Poulin R. 2004: Stability of Corynosoma populations with fluctuating population densities of the seal definitive host. Parasitology 129: 635-642.

Valtonen E.T., van Maren M.J., Timola O. 1983: A note on the intermediate hosts of Echinorhynchus gadi Zoega, in Müller (Acanthocephala) in the Baltic Sea. Aquil. Ser. Zool. 22: 93-97.

Wilson K., Grenfell B.T. 1997: Generalized linear modelling for parasitologists. Parasitol. Today 13: 33-38.

ZdZitOWIECKi K., Presler P. 2001: Occurrence of Acanthocephala in intermediate hosts, Amphipoda, in Admiralty Bay, South Shetland Islands, Antarctica. Pol. Polar Res. 22: 205-212.

Cite this article as: Benesh D.P., Aura R.-L., Andersin A.-B., Valtonen E.T. 2015: The occurrence of Echinorhynchus salmonis Müller, 1784 in benthic amphipods in the Baltic Sea. Folia Parasitol. 62: 052. 